Akreditasi KEMENRISTEKDIKTI, Nomor: 148/M/KPT/2020
http://iurnal.stkippersada.ac.id/jurnal/index.php/VOX

\title{
ANALISIS PENGGUNAAN ALAT BANTU PENERJEMAHAN TERHADAP MAHASISWA SEKOLAH TINGGI BAHASA HARAPAN BERSAMA
}

\author{
Agustina Hendra \\ Bahasa Mandarin, Sekolah Tinggi Bahasa Harapan Bersama \\ Email:agustinahendra26@gmail.com
}

\section{INFO ARTIKEL}

Riwayat Artikel:

Menerima : 21 Agustus 2020

Revisi : 14 Oktober 2020

Diterima : 27 Oktober 2020

\section{Kata Kunci:}

penerjemahan; bahasa

Mandarin; mesin penerjemah

Keywords:

translation; Mandarin;

translator engines

\section{Korespondensi:}

Agustina Hendra

Bahasa Mandarin, Sekolah Tinggi

Bahasa Harapan Bersama

Email:

agustinahendra26@gmail.com

\section{ABSTRAK}

Penerjemahan adalah suatu proses mengartikan suatu bahasa ke bahasa lain, baik secara lisan maupun tertulis, misalnya menerjemahkan dari Bahasa Mandarin ke Indonesia, atau menerjemahkan dari Indonesia ke Mandarin. Penerjemahan juga bisa diartikan sebagai kegiatan mengartikan suatu simbol ke bahasa lain, misalnya, jika lampu merah menyala, artinya kendaraan atau manusia yang melintas, harus berhenti. Didalam proses penerjemahan suatu teks atau dokumen, penerjemah harus menguasai kosakata yang diperlukan atau kata yang umum dipergunakan, misalnya jika menerjemahkan hal-hal yang berhubungan dengan bidang kesehatan, maka penerjemah harus menguasai istilah-istilah yang ada di dalamnya, termasuk nama-nama penyakit, alat-alat yang dipakai di dalam kedokteran, dan lain sebagainya.

Sejalan dengan kemajuan teknologi informasi dan komunikasi, munculah mesin penerjemah seperti google translate, pleco, dan lain-lain, dan menerjemahkan menjadi lebih mudah. Melalui tugas penerjemahan yang dikerjakan oleh 38 mahasiswa, penulis menyadari bahwa banyak mahasiswa yang sangat bergantung dengan alat bantu penerjemah. Mahasiswa menggunakan alat bantu penerjemah untuk memperbaiki tatanan kata dan mengerjakan semua tugas penerjemahan, ada yang bahkan tidak mensortir hasil terjemahan, dengan kata lain mengambil mentah-mentah hasil terjemahan tersebut.

\section{ABSTRACT}

Translation is a process of interpreting a language into another language, either orally or in writing, for example translating from Mandarin to Indonesian, or translating from Indonesia to Mandarin. Translation can also be interpreted as the activity of interpreting a symbol into another language, for example, if a red light is on, it means that a passing vehicle or human must stop. In the process of translating a text or document, the translator must master the necessary vocabulary or words that are commonly used, for example if translating matters related to the health sector, the translator must master the terms in it, including names of diseases, tools used in medicine, and so on. In line with advances in information and communication technology, machine translators such as google translate, pleco, and others have emerged, and translating has become easier. Through translation assignments carried out by 38 students, the authors realized that many students were very dependent on translator aids. Students use translator tools to improve word order and do all translation assignments, some do not even sort the translation results, in other words take the translation results raw.

\section{PENDAHULUAN}

Bahasa adalah jembatan komunikasi antar manusia. Menurut Kamus Besar Bahasa
Indonesia (KBBI) bahasa adalah sistem lambang bunyi yang arbitrer, yang digunakan oleh anggota suatu kelompok masyarakat untuk 
melakukan kegiatan interaksi maupun bekerja sama. Bahasa Mandarin adalah bahasa yang internasional ke-2, dan merupakan bahasa dengan penutur terbanyak di dunia.

Seiring dengan banyaknya kerjasama yang terjalin dengan China, maka diperlukan penguasaan Bahasa Mandarin yang baik untuk mempererat kerjasama yang telah terjalin sebelumnya. Penguasaan bahasa ini juga meliputi beberapa aspek, contohnya penguasaan istilah dalam bidang ekonomi, politik, kesehatan, dan lain-lain.

Oleh karena pentingnya bahasa di dalam kehidupan sehari-hari, maka di dalam proses penerjemahan di perlukan penggunaan bahasa yang baik dan relevan dan sesuai, diperlukan kemampuan menterjemahkan dan menyimpulkan isi naskah terjemahan, supaya tidak terjadi kesalahan dalam penafsiran.

Penerjemahan terbagi atas penerjemahan lisan dan tertulis. Menurut Machali, penerjemahan adalah,: "upaya "mengganti" teks bahasa sumber dengan teks yang sepadan dalam bahasa sasaran dan yang diterjemahkan adalah makna sebagaimana yang dimaksudkan pengarang”. Di dalam teorinya, penerjemahan dapat dengan mudah dipahami, yaitu menerjemahkan bahasa sumber ke bahasa tujuan atau bahasa sasaran, akan tetapi didalam prakteknya, penerjemahan tidak semudah yang dibayangkan, ada hal-hal atau istilah yang ada di dalam Bahasa Mandarin, tapi di Bahasa Indonesia tidak ada kata yang artinya benarbenar dapat mewakili atau sepadan, atau orang Indonesia tidak berujar seperti itu, sehingga akan ada kesulitan dalam mencari kata pengganti untuk mengungkapkannya. Selain harus bisa mengerti dan memahami bahasa sumber, penerjemah juga dituntut bisa menyampaikan kembali bahan sumber dalam bentuk bahasa tujuan/sasaran dalam tatanan bahasa yang benar dan baku, jadi, seorang penerjemah dituntut harus mempunyai tata bahasa yang baik dan benar, jangan sampai hasil penerjemahan malah menyesatkan pemakai.

Mata kuliah Penerjemahan Dasar di Prodi S1 Bahasa Mandarin Sekolah Tinggi Bahasa Harapan Bersama mulai diajarkan pada mahasiswa semester 3, dalam makul ini, mahasiswa diperbolehkan menggunakan semua perangkat dan alat bantu, misalnya kamus dan $\mathrm{hp}$ (google translate dan pleco), tetapi tidak ada mahasiswa yang membawa kamus, semuanya menggunakan google translate karena lebih praktis dan tidak perlu membolak-balik kamus untuk mencari artinya, serta google translate mempunyai fitur yang bisa menterjemahkan kalimat panjang. Peneliti telah menganalisis tugas mahasiswa yang telah dikumpulkan, didalam menerjemahkan tugas, tugas yang dikerjakan dengan menggunakan google translate akan sangat jelas terlihat, mahasiswa memotret atau memindai teks sumber ke google translate, kemudian selang beberapa detik kemudian, terjemahan akan muncul.

\section{METODE PENELITIAN}

Untuk menghasilkan suatu penelitian yang valid, diperlukan metode yang benar untuk mencapai tujuan tersebut, begitu juga dengan penelitian ini, oleh karena itu, penulis juga menggunakan metode penelitian yang dianggap paling sesuai. 
Menurut Sugiyono "Metode penelitian dapat diartikan sebagai cara ilmiah untuk mendapatkan data yang valid dengan tujuan dapat ditemukan, dikembangkan, dan dibuktikan, suatu pengetahuan tertentu sehingga pada gilirannya dapat digunakan untuk memahami, memecahkan dan mengantisispasi masalah".

Penulis menggunakan metode penelitian metode deskriptif di dalam penelitian ini. Metode deskriptif adalah suatu jenis penelitian yang mendeskripsikan kejadian atau kasus berdasarkan fakta-fakta atau yang tampak. Dalam penelitian ini, penulis menganalisis pengaruh penggunaan alat bantu penerjemahan melalui tugas-tugas yang diberikan kepada sebanyak 38 mahasiswa, kemudian mengambil kesimpulan dari hasil tugas tersebut.

\section{HASIL DAN PEMBAHASAN}

Penerjemahan mempunyai fungsi yang besar di dalam komunikasi, penerjemahan juga merupakan suatu proses yang kompleks, bukan hanya diperlukan kemampuan berbahasa asing, tetapi juga diperlukan kemampuan akan pengetahuan yang lain, misalnya jika seorang penerjemah diminta menerjemahkan tentang politik, penerjemah harus bisa menguasai istilah-istilah tersebut walaupun penerjemah tidak pernah belajar tentang politik. Oleh karena itu diperlukan ketepatan dalam menterjemahkan setiap kata atau kalimat dari bahasa sumber maupun teks sumber.

Menerjemahkan adalah proses memproduksi kata dari bahasa sumber ke bahasa sasaran, jika hasil bahasa sasaran tidak sepadan dengan bahasa sumber, maka akan tejadi pergeseran/perubahan makna. Oleh karena perubahan makna yang terjadi, maka akan terjadi ketidaksesuaian atau ketidaksepadanan makna kata.

Menurut Wibowo "terjemahan yang baik harus memperhatikan unsur kesepadanan antara bahasa sumber dan bahasa sasaran serta aspek keberterimaan oleh pembaca". Menurut Newmark, ada delapan metode penerjemahan, yang terbagi atas empat metode yang

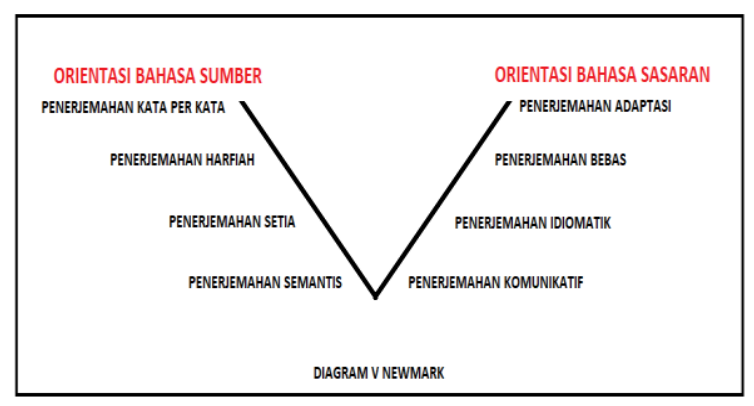

Gambar 1. Diagram 5 Newmark

Metode penerjemahan yang beorientasi pada bahasa sumber $(\mathrm{BSu})$ antara lain:

1. Penerjemahan kata per kata (word by word translation) dilakukan dengan cara menerjemahkan secara kata per kata, satu demi satu kata, satu suku kata demi suku kata, sehingga tidak ada perubahan terhadap susunan kata bahasa sasaran. Metode penerjemahan ini bisa digunakan jika susunan bahasa sumber dan bahasa sasaran sama, tidak ada perbedaan sama sekali.

2. Penerjemahan harfiah (literal translation) menurut Wibowo adalah penerjemahan dengan kata per kata namun struktur dan susunan katanya telah disesuaikan dengan bahasa sasaran, metode ini dapat dipergunakan dengan syarat apabila bahasa 
sumber dan bahasa sasaran memiliki struktur yang berbeda.

\section{Penerjemahan setia (faithful} translation) yaitu metode penerjemahan yang mengacu kepada makna kontekstual dan sebisa mungkin mempertahankan atau tidak merubah bentuk dari bahasa sumber.

4. Penerjemahan semantis yaitu salah satu bentuk penerjemahan yang lebih menitikberatkan estetika dari bahasa sumber, metode ini bisa diaplikasikan dengan mempertimbangkan kewajaran antara bahasa sumber dan bahasa sasaran.

Metode penerjemahan yang berorientasi pada bahasa sasaran (BSa) antara lain:

1. Penerjemahan adaptasi (adaptation translation) yaitu metode penerjemahan yang tidak terikat dan yang paling mendekati bahasa sasaran, istilah-istilah yang digunakan di bahasa sasaran sangat mendekati istilah yang dipakai di bahasa sumber. Metode penerjemahan ini paling sering dijumpai pada novel, teks drama ataupun puisi.

2. Penerjemahan bebas (free translation) yaitu penerjemahan yang sangat menitikberatkan pada isi bahasa sumber daripada struktur kalimat bahasa sumber, sehingga terkadang metode penerjemahan ini menghasilkan penerjemahan yang agak panjang serta bertele-tele.

3. Penerjemahan idiomatik (idiomatic translation) menurut Wijayanti adalah penerjemahan yang menggunakan kosakatakosakata yang berasal dari bahasa sasaran, bukan dari bahasa sumber.

4. Penerjemahan komunikatif (communicative translation) yaitu metode penerjemahan yang sangat komunikatif karena mudah dipahami oleh orang yang membaca, terikat pada bahasa sasaran tetapi tidak mengganti bentuk dari bahasa sumber. Dalam prakteknya, metode penerjemahan ini menekankan pada isi tapi tidak berarti menerjemahkan secara bebas.

Pada 7 minggu pertama di dalam kelas mata kuliah teori penerjemahan dasar, mahasiswa diperbolehkan menggunakan semua alat bantu penerjemahan, termasuk pleco dan google translate, kebijakan ini diberikan oleh dosen yang mengajar karena mengingat kosakata mahasiswa yang masih sedikit, di samping mengerjakan tugas yang diberikan di mata kuliah penerjemahan, mahasiswa juga bisa melalui tugas ini mendapatkan kosakata baru.

Dari hasil analisis penulis terhadap 38 mahasiswa, terdapat sebanyak 27 mahasiswa atau $81.8 \%$ mahasiswa yang sangat tergantung dengan alat bantu penerjemahan, mahasiswa mengetikkan kata yang ingin diterjemahkan ke pleco dan google translate, dikarenakan perkembangan yang makin canggih dari google translate, memungkinkan pengguna untuk bisa langsung memindai gambar yang berisi teks, dalam hitungan detik, hasil terjemahan akan langsung ditampilkan, oleh karena itu, bahkan ada mahasiswa yang langsung memindai isi teks yang harus diterjemahkan ke bahasa sasaran. Efek yang ditimbulkan sangat fatal, mahasiswa bukan hanya tidak mendapatkan pengetahuan apa-apa tapi juga mengakibatkan munculnya budaya malas berpikir pada mahasiswa. Hal ini mengakibatkan hasil penerjemahan atau bahasa sasaran yang 
dihasilkan menjadi tidak bisa dipertanggungjawabkan kebenarannya, karena satu kata bisa saja mengandung banyak arti, misalnya :

a. kata “家”, bisa saja berarti "rumah" atau "keluarga", jika BSu: 我想要一个家, maka Bsa yang tepat adalah "saya ingin berkeluarga", atau "saya ingin mempunyai keluarga/menikah", di dalam kalimat tersebut, “家” di sini tidak bisa diterjemahkan sebagai "rumah". Bisa disimpulkan bahwa untuk menerjemahkan kata yang mempunyai banyak arti，harus memperhatikan “上下文”atau keseluruhan dari makna kalimat yang ada, jika tidak, akan terjadi kesalahan di dalam proses penerjemahan itu sendiri.

b. $\mathrm{BSu}$ : 一切都起因于某 个星期五下午的政治学习。

BSa (mahasiswa) : Semuanya disebabkan karena pembelajaran politik pada beberapa Jumat sore.

$\mathrm{BSa}$ : Semuanya berawal dari seminar politik pada suatu sore di hari Jumat.

Ada juga sebagian mahasiswa yang bijak menggunakan alat bantu penerjemahan, mereka mencari kosakata yang tidak dikenal di pleco, google translate ataupun baidu translate, kemudian menyepadankan dengan makna yang tersirat dari bahasa sumber, cara seperti ini menghasilkan penerjemahan yang lebih akurat dan bisa dipertanggungjawabkan kebenarannya.

Pada minggu ke 8 atau setelah berakhirnya Ujian Tengah Semester, mahasiswa tidak diperbolehkan lagi menggunakan alat bantu penerjemah secara random, kecuali buku kamus, semua handphone mahasiswa harus disimpan di meja dosen. Dari tugas yang dikerjakan mahasiswa, peneliti mendapati bahwa sebanyak 60 persen mahasiswa tidak mengerti sepenuhnya apa yang ingin diterjemahkan, karena selama ini terlalu tergantung kepada alat bantu lainnya sehingga ketika alat bantu tidak ada mereka sangat kelabakan. Selain itu ada juga mahasiswa yang tidak mengalami kesulitan di dalam menerjemahkan, karena selama 7 minggu perkuliahan yang telah berlalu, mereka tidak sepenuhnya mengandalkan terjemahan dari alat bantu, kosakata yang ditemui sebelumnya sudah ada di ingatan, jadi ketika kosakata yang sama keluar untuk kedua kalinya, mahasiswa bersangkutan sudah tahu makna dan cara penggunaannya di dalam kalimat. Terakhir, ada juga mahasiswa yang kesulitan menyimpulkan BSu (Mandarin) ke BSa (Bahasa Indonesia), padahal kemampuan Bahasa Mandarin mereka dari awal sudah bagus, hal ini dikarenakan frekuensi mereka menggunakan Bahasa Indonesia lebih sedikit dibandingkan dengan frekuensi bahasa lainnya, misalnya Bahasa Tiocu, Bahasa Khek, ini sangat berpengaruh di dalam proses menerjemahakan bahasa asing ke Bahasa Indonesia. Mahasiswa tipe ini tahu arti kata tersebut, bisa menjabarkan secara oral, tetapi jika diminta untuk memakai istilah atau Bahasa Indonesia yang pas, mereka akan mengalami kesulitan.

\section{SIMPULAN}


Dari hasil pembahasan di atas dapat disimpulkan bahwa 81.8 persen mahasiswa secara garis besar sangat bergantung dengan alat bantu penerjemah, hal ini disebabkan oleh beberapa faktor, antara lain:

1. Teks sumber mengandung banyak kata-kata yang asing, yang belum pernah dilihat sebelumnya, jadi otak sudah mengisyaratkan bahwa ini susah, maka mahasiswa akan langsung menggunakan alat bantu.

2. Mahasiswa kesulitan dalam menterjemahkan kalimat panjang karena mereka tidak mengerti arti kalimat, tidak mengerti kata per kata, misalnya kata 目的, ada mahasiswa yang menterjemahkannya menjadi "mata depan", sedangkan arti sebenarnya adalah "tujuan". Mereka tidak mencoba menganalisa keseluruhan kalimat terlebih dahulu, dan mereka lupa bahwa 1 kata bisa mempunyai banyak arti, tergantung dimana ia diletakkan, dan harus memahami isi kalimat tersebut baru bisa diambil kesimpulan.

3. Mahasiswa tidak berusaha berpikir secara logis, teks sasaran yang muncul di google translate langsung di copy tanpa dicerna, apakah jika dibaca ke Bahasa Indonesia, kalimat tersebut bermasalah atau tidak, logis atau tidak, sesuai atau tidak dengan konteks Bahasa Indonesia.

4. Mahasiswa kurang menguasai penggunaan Bahasa Indonesia yang baik dan benar, dari hasil wawancara dengan mahasiswa, dapat diketahuidiketahui bahwa hampir 100 persen mahasiswa merupakan lulusan dari sekolah swasta yang bisa dibilang jarang menggunakan bahasa Indonesia kecuali di dalam proses belajar mengajar. Bahasa yang dipergunakan untuk komunikasi antar sesama siswa adalah bahasa daerah atau dialek (Tiocu dan Khek), sehingga berakibat pembendaharaan kata di dalam Bahasa Indonesia juga sedikit. Hal ini mengakibatkan mahasiswa mengalami kesulitan ketika menerjemahkan Tsu yang berbahasa asing ke Tsa Bahasa Indonesia.

\section{DAFTAR RUJUKAN}

Habibullah, Mosleh, 2015. Proses dan Hasil Penerjemahan Mahasiswa

Mahasiswa Translation Theory and Practice Di STAIN Pamekasan). Nuansa, Vol. 12 No. 1 Januari-Juni 2015.

Newmark, P., 1988. A Textbook of Translation. New York: Prentice Hall.

Sufianto, Agustinus, 2010. KESALAHAN PENERJEMAHAN BAHASA MANDARIN PADA MAHASISWA SASTRA CHINA BINUS UNIVERSITY PADA MATA KULIAH TERJEMAHAN UMUM. Humaniora Vol.1 2 Oktober 2010: 737-745

Wibowo, A.S., 2019. Analisis Metode Penerjemahan Bahasa Mandarin ke Bahasa Indonesia pada Mahasiswa Semester 3 Program Studi Bahasa Mandarin S1 Sekolah Tinggi Bahasa Harapan Bersama. APSMI

Wijayanti, G., 2018. "Metode Penerjemahan Bahasa Mandarin ke Bahasa Indonesia pada Buku Ajar Bahasa Tionghoa". Mimbar Sejarah, Sastra, Budaya dan Agama, vol. XXIV No.2. 